\title{
Production of Construction Bricks by Partial Replacement of Waste Plastics
}

\author{
K. Prem Kumar ${ }^{1}$, M.Gomathi ${ }^{2}$ \\ ${ }^{1,2}$ (Assistant Professor, Civil Engineering Department, Periyar Maniammai University, Thanjavur, India- \\ 613403)
}

\begin{abstract}
Plastics are the one which posses important problem in disposal and still the absolute solutions were not determined. For solving this issue plastics were replaced in a bricks to achieve the nominal strength. High-density polyethylene (HDPE) and polyethylene (PE) plastic bottles and bags were collected and cleaned then mixed with sand with various proportions to achieve the strength of the nominal bricks and also to posses thermal and sound insulation. To predict the strongest specimen, $0 \%$ to $20 \%$ of replacement proportion was done by crushed plastics. The result in increase the strength of structure and weight reduction of bricks was tested for compressive strength and water absorption test. Based on the comparison of conventional and fly ash plastic brick, optimum strength was analyzed. This paper reviews the reduction of plastic disposal and the results are clearly shows that some part of plastics can be definitely used in the production of bricks.
\end{abstract}

Keywords: Fly ash plastic brick, Plastic waste, Compressive strength, Environment

\section{Introduction}

The amount of generation of plastic waste is increasing day by day and proper disposal method for waste plastics are not channelized even today. Plastic is classified into two types, thermoplastic and thermoset plastic. Thermoplastic is a type of plastic which is recyclable and further molded into another structure. These plastics are polyethylene, polypropylene, polyamide, polyoxymethylene, polytetrafluroethylene and polyethyleneterepthalate. Second type is thermosetting plastic This type of plastic have a property of unchangeable molecular chains because molecular chains are strongly bonded with crosslinks. Some examples are melamine, epoxy resin, polyurethane, phenolic and silicone. Reuse of thermosetting plastic waste can help in reducing the pollution caused due to burning, and cost will also be reduced up to some extent[1]. In India used plastics are not properly disposed and it creates the lot of environmental issues. Open burning of plastics leads to air pollution. To avoid these problems reusing of plastics should be improvised for several works with economic and environmental feasibility. Recycling the plastics has advantages since it is widely used and has a long service life, which means that the waste is being removed from the waste stream for a long period. Because the amount of clay required to make bricks is large, the environmental benefits are not only related to the safe disposal of bulk waste, but also to the reduction of environmental impacts that arise due to burning of plastics[2].In this work, raw materials used are fly ash, waste plastics and lime with different proportions. The different types of bricks were tested to find the compressive strength and water absorption value. This paper mainly focused to find the proper disposal options for plastics and also to motivate the use of plastic in the production of building materials etc.

\section{Meterials and Methods}

Gypsum: Hydrated calcium sulphate are called gypsum. Gypsum should have minimum 35\% purity and 5 to $15 \%$ may be used.

Lime: Quick Lime or hydrated lime or both can be mixed in the composition. Lime should have minimum 40\% Cao content.

Sand: River sand should be clean \& coarse. About 10 to $20 \%$ may used. Specific gravity has 2.5 and unit weight $1.6 \mathrm{~g} / \mathrm{cc}$

Fly Ash: Fine smooth and grey in color, Having no virtual odour, Non - Toxic, Non - Flammable, Non Explosive. Fly ash does not have any adverse health effects, however when the exposure to fly ash is more than the recommended limits, the necessary protective equipment for respiratory / eye / hand / skin protection to be used. Specific Gravity 2.54 to $2.65 \mathrm{gm} / \mathrm{cc}$, Bulk Density $1.12 \mathrm{gm} / \mathrm{cc}$, Fineness 350 to $450 \mathrm{~m} / \mathrm{Kg}$

Plastic waste : Plastic wastes are crushed as fine particles by a plastic crusher machine and passed through the $4.75 \mathrm{~mm}$ sieve and retained on $2.36 \mathrm{~mm}$ sieve, then it is collected and using in the preparation of plastic brick.

Manufacturing Process: Fly ash (55\%), Lime (15\%), Gypsum (5\%), sand plus waste plastics in various proportion are manually feed into a pan mixer where water is added to the required proportion for homogeneous mixing. The proportion of raw material may vary depending upon quality of raw materials. After mixing, then filled in the wooden pallets use in hand press Than the bricks are placed on and kept as it is 
for two days thereafter where they are water cured for 7-10 days. The bricks are sorted and tested before dispatch

Absorption Test: This test is carried out to determine the amount of water absorbed by the brick. When immersed in water for a period of 24 hours it should not, in any case, exceed $20 \%$ of weight of dry brick. This test is carried out for all the samples of fly ash bricks and clay bricks.

Compressive Strength Test: This is the main test conducted to find the suitability of the brick for construction work. This test is executed with the help of compression testing machine. As per IS:3495-Part 1-1992, removed unevenness observed in the bed faces to provide two smooth and parallel faces by grinding. Immersed in water at room temperature, removed all voids in the bed face flush with cement mortar. Then the brick was stored under the damp jute bags for 24 hours followed by immersion in clean water for 3 days. Finally traces of moisture removed to make the brick ready for compressive strength test. After placing the test specimen load was applied axially at a uniform rate of $140 \mathrm{~N} / \mathrm{mm}^{2}$ per minute till failure occurs. The load at failure shall be the maximum load at which the specimen fails to produce any further increase in the indicator reading on the testing machine. A brick after undergoing compression test, this test is carried out for both fly ash bricks and clay bricks.

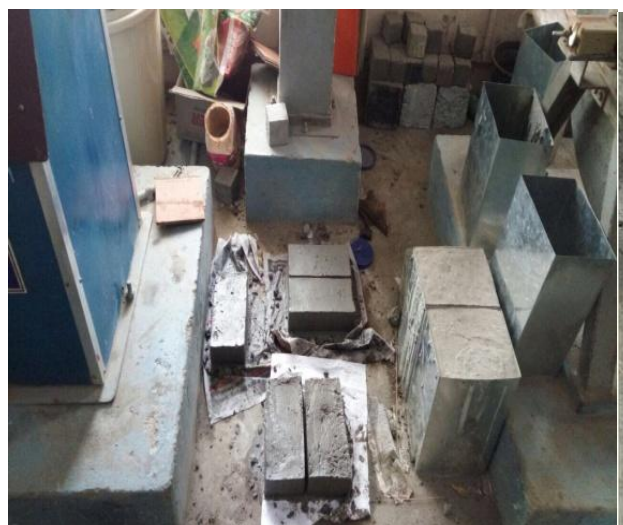

Fig 1: Raw Brick

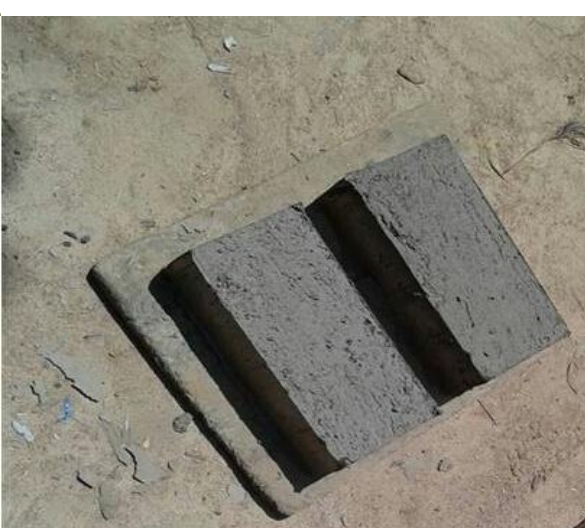

Fig 2: Fired Brick

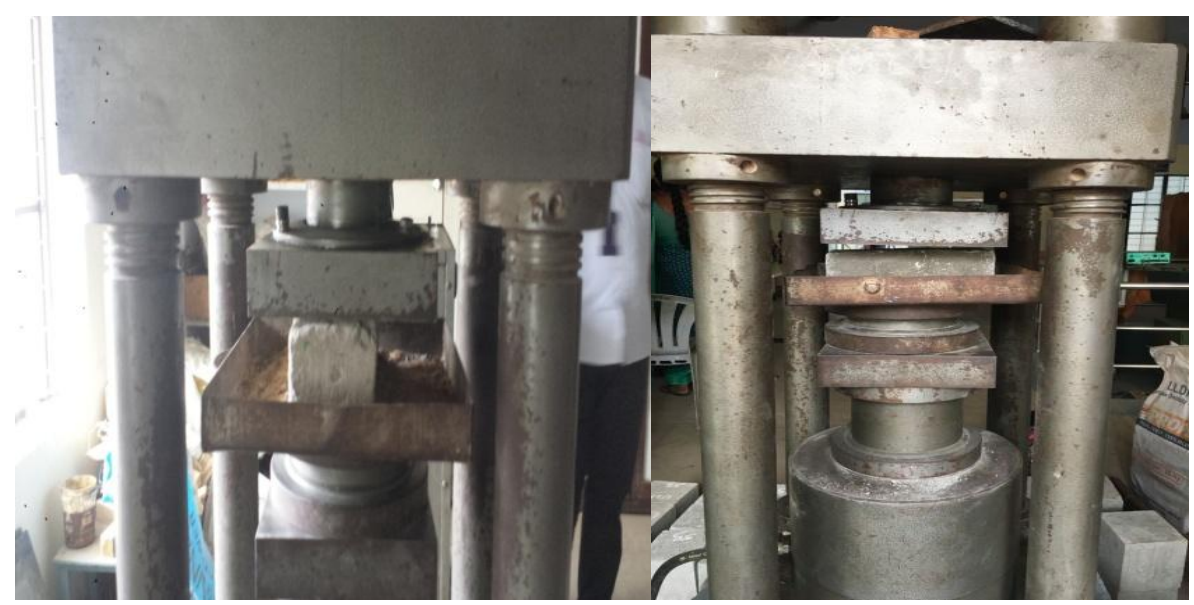

Fig 3: Compressive strength test set up for prepared specimen

Mix Proportion: To find the optimum strength of fly ash plastic brick the following mix proportion are arrived by trial and error method is given in table 1 . The required quantity of materials to make one brick is considered by taking brick weight of $2.6 \mathrm{~kg}$ is given in table 2

Table 1: Material proportions for different combinations

\begin{tabular}{|c|c|c|c|c|c|}
\hline Proportions & $\begin{array}{c}\text { Fly Ash } \\
(\boldsymbol{\%})\end{array}$ & $\begin{array}{c}\text { Sludge Lime } \\
(\boldsymbol{\%})\end{array}$ & $\begin{array}{c}\text { Gypsum } \\
(\boldsymbol{\%})\end{array}$ & $\begin{array}{c}\text { Fine aggregate } \\
(\mathbf{\%})\end{array}$ & $\begin{array}{c}\text { Plastic } \\
(\boldsymbol{\%})\end{array}$ \\
\hline I & 55 & 15 & 5 & 25 & 0 \\
\hline II & 55 & 15 & 5 & 20 & 5 \\
\hline III & 55 & 15 & 5 & 15 & 10 \\
\hline IV & 55 & 15 & 5 & 10 & 15 \\
\hline V & 55 & 15 & 5 & 5 & 20 \\
\hline
\end{tabular}


Table 2: Quantity of Materials used

\begin{tabular}{|c|c|c|c|c|c|}
\hline Proportions & Fly Ash (g) & Sludge Lime (g) & Gypsum (g) & Fine aggregate (g) & Plastic (g) \\
\hline I & 1430 & 390 & 130 & 650 & 0 \\
\hline II & 1430 & 390 & 130 & 520 & 130 \\
\hline III & 1430 & 390 & 130 & 390 & 260 \\
\hline IV & 1430 & 390 & 130 & 260 & 390 \\
\hline V & 1430 & 390 & 130 & 130 & 520 \\
\hline
\end{tabular}

\section{Experimental test \& Results}

Compressive Strength Test: IS: 3495-Part 1-1992 Compressive strength of the bricks were determined for the bricks having various mix proportions and it is clearly observed that the optimum replacement of waste plastic is $5 \%$. Compressive strength of the fly ash plastic brick is high compared than conventional brick.

Table 3: Compressive Strength of five bricks with various proportions

\begin{tabular}{|c|c|c|c|c|c|c|}
\hline \multirow{2}{*}{ Proportions } & \multicolumn{7}{|c|}{ Compressive Strength (N/mm $\mathbf{~}$} \\
\cline { 2 - 7 } & Brick 1 & Brick 2 & Brick 3 & Brick 4 & Brick 5 & Average \\
\hline I & 4.25 & 4.32 & 4.12 & 4.3 & 3.8 & $\mathbf{4 . 1 5}$ \\
\hline II & 4.7 & 4.63 & 4.45 & 4.32 & 4.4 & $\mathbf{4 . 5}$ \\
\hline III & 4.09 & 4.32 & 3.64 & 4.09 & 3.86 & $\mathbf{4}$ \\
\hline IV & 3.85 & 3.7 & 3.4 & 3.95 & 4.1 & $\mathbf{3 . 8}$ \\
\hline V & 3.13 & 3.32 & 3.46 & 2.87 & 3.47 & $\mathbf{3 . 2 5}$ \\
\hline
\end{tabular}

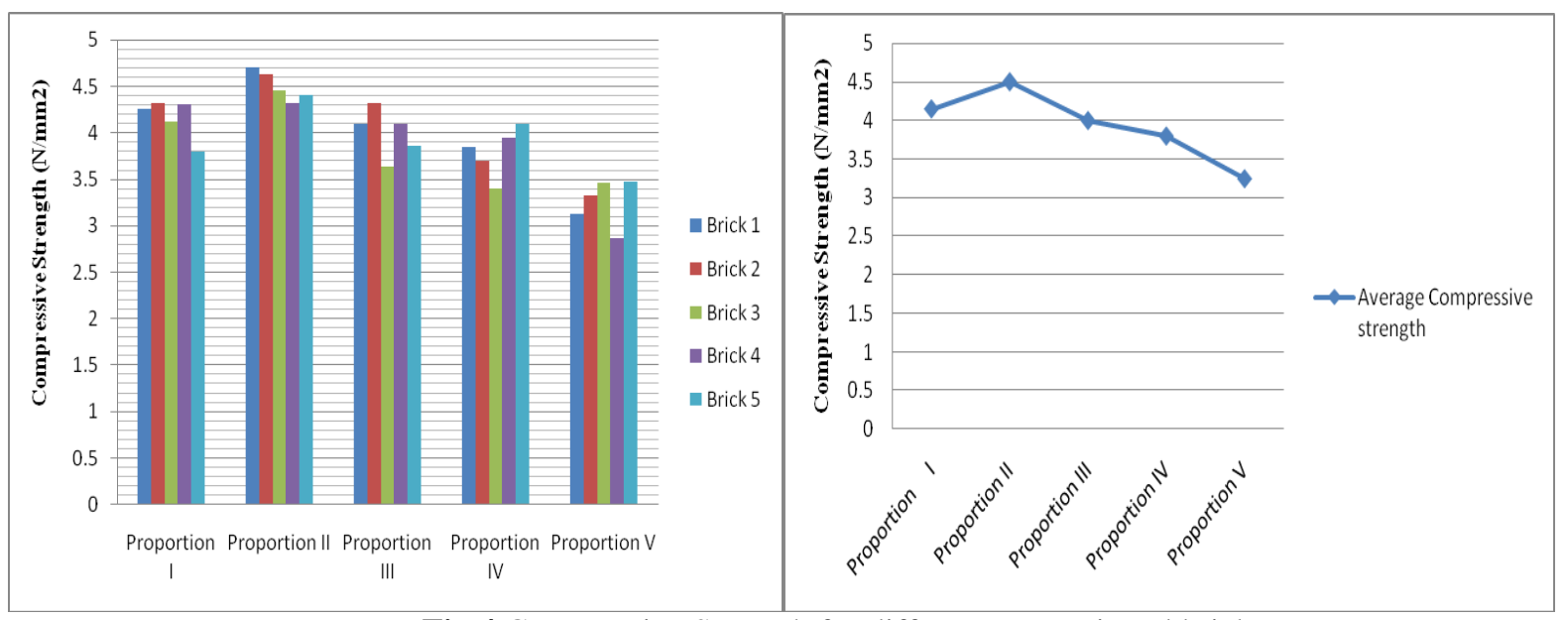

Fig.4 Compressive Strength for different proportioned bricks

Water Absorption Test: This test is carried out to determine the amount of water absorbed by the brick. As per IS:3495-Part 2-1992, after immersed in cold water for a period of 24 hours, water absorption shall not be more than $20 \%$ for up to class 12.5 and $15 \%$ of weight for higher classes. Initially 5 bricks were taken and removed all the loose particles. Dry the bricks in a ventilated oven at a temperature of $110^{\circ} \mathrm{C}$ till the brick attain substantially constant weights. Cooled the bricks at room temperature and taken weight of each sample $\mathrm{W}_{1}$. Then immersed the bricks in clean water at temperature of $25^{\circ} \mathrm{C}$ to $29^{\circ} \mathrm{C}$ for $24 \mathrm{hrs}$ and removed the specimen after $24 \mathrm{hr}$ wipe our water with damp cloth \& weight each sample W2. Finally the percentage of water absorbed for each brick was calculated by the following formula.

Water Absorption $\left.=\left[\left(\mathrm{W}_{2}-\mathrm{W}_{1}\right) / \mathrm{W}_{1}\right)\right] \times 100$

$\mathrm{W} 2=$ weight of soaked brick

W1=weight of dry brick

Table 4: Water absorption value for conventional brick

\begin{tabular}{|c|c|c|c|c|c|c|}
\hline \multirow[b]{2}{*}{$\begin{array}{l}\text { Sl. } \\
\text { No }\end{array}$} & \multicolumn{3}{|c|}{ Dimension in $\mathbf{c m}$} & \multicolumn{2}{|c|}{ Weight in kg } & \multirow[b]{2}{*}{$\begin{array}{c}\text { Water Absorption } \\
(\%)\end{array}$} \\
\hline & $\mathbf{L}$ & B & D & $\begin{array}{c}\text { BEFORE } \\
\text { IMMERSION }\left(\mathrm{W}_{1}\right)\end{array}$ & $\begin{array}{c}\text { AFTER } \\
\text { IMMERSION }\left(\mathrm{W}_{2}\right) \\
\end{array}$ & \\
\hline 1. & 22 & 10 & 7 & 2.931 & 3.235 & 10.37 \\
\hline 2. & 22 & 10 & 7 & 2.957 & 3.295 & 11.43 \\
\hline 3. & 22 & 10 & 7 & 2.966 & 3.275 & 10.42 \\
\hline 4. & 22 & 10 & 7 & 2.941 & 3.275 & 11.36 \\
\hline 5. & 22 & 10 & 7 & 2.859 & 3.210 & 12.28 \\
\hline & & & & & Average & 11.17 \\
\hline
\end{tabular}


Table 5: Water absorption value for Plastic replaced bricks in various proportions

\begin{tabular}{|c|c|c|c|c|c|c|}
\hline \multirow{2}{*}{$\begin{array}{c}\text { \% of } \\
\text { Plastic }\end{array}$} & \multicolumn{5}{|c|}{ Water Absorption (\%) } & \multirow{2}{*}{$\begin{array}{c}\text { Average Water } \\
\text { Absorption (\%) }\end{array}$} \\
\cline { 2 - 6 } & Brick 1 & Brick 2 & Brick 3 & Brick 4 & Brick 5 & 9.2 \\
\hline $5 \%$ & 9.13 & 9.18 & 9.25 & 9.2 & 9.3 & 9.1 \\
\hline $10 \%$ & 9.1 & 9 & 9.2 & 9.15 & 9.23 & 9.9 \\
\hline $20 \%$ & 10 & 9.85 & 9.9 & 10.15 & 9.7 & 10.7 \\
\hline
\end{tabular}
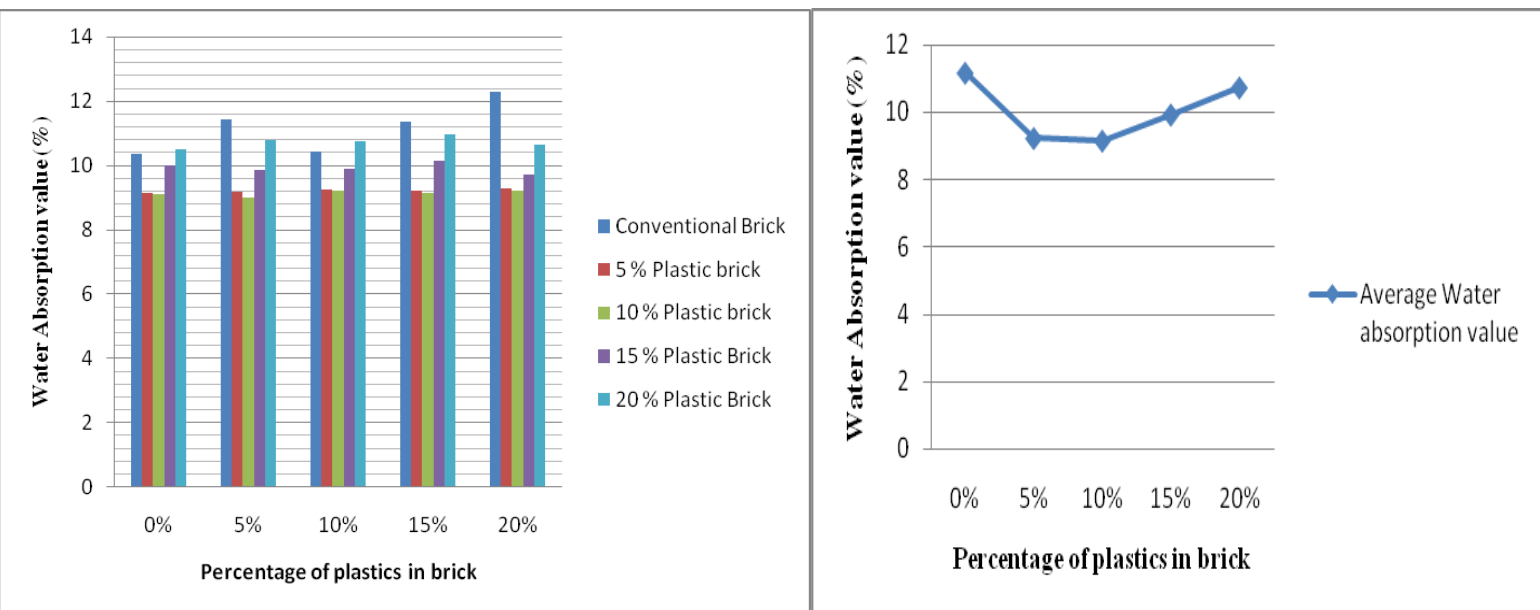

Fig.5: Water absorption value for conventional and plastic bricks

\section{Conclusion}

A study on the effect of addition of waste plastics to bricks production in different percentages subjected to water curing is conducted to find the characteristic compressive strength and water absorption value of bricks. The test results show that the partial replacement of natural sand by crushed waste plastics at the levels of 5 to 10 percentages has good effects on compressive strength of the bricks. However 20 percentage of replacement of waste plastics reduces the compressive strength compared with that of the control sample. Water absorption has attained desirable value for all the type of mix proportions. Overall, the plastic which makes environmental issues can be used in brick mixtures as a good substitute for natural sand.

\section{References}

[1] Alkunte C.V. , Pankaj Vashisth, Khandelwal Aditya, Use of Thermoset in Manufacturing of Flyash Bricks with Economic Feasibility, International Journal of Engineering and Management Research, ISSN (ONLINE): 2250-0758, ISSN (PRINT): 23946962, Volume-5, Issue-2, April-2015

[2] Dinesh.S, Dinesh.A, Kirubakaran.k utilisation of waste plastic in manufacturing of bricks and paver blocks, International Journal of Applied Engineering Research, ISSN 0973-4562 Vol. 11 No.3 (2016)

[3] D.W.Gawatre, Vivek S.Damal, Saurabh S.Londhe, Environmental Issues of Plastic waste use in Concrete, International, Journal of Innovative Research in Advanced Engineering (IJIRAE) ISSN: 2349-2163 Issue 5, Volume 2 (May 2015)

[4] Sandeep yadav, suyash agnihotri,shivam gupta, rishabh kumar tripathi, Incorporation of STP sludge and flyash in brick manufacturing: an attempt to save the environment, International Journal advancements in Research \& Technology, volume 3, issue 5, ISSN: 2278-7763(May 2014)

[5] Hegazy,B.E, Brick making from water treatment plant sludge, Journal of Engineering and Applied Science,54(6):599-616(2007)

[6] Phaiboon panyakapo, mallika panyakapo, Reuse of thermosetting plastic waste for light weight concrete, Science direct(Waste Management), vol.28(9):1581-1588 (2008)

[7] Indian Standards for Methods of tests of burnt clay building bricks, IS 3495 (Part 1\&2) :1992

[8] Appukutty P, Substitution of quarry dust to sand for mortar in brick masonry works, International Journal on Design and Manufacturing Technologies, Vol.3, No.1 (2009)

[9] IS: 2117-1975 Guide for Manufacture of Hand- Made Common Burnt Clay Building Bricks (Second Revision)

[10] Dipankar sarkar, manish pal, Ashoke K.sarkar, Study on plastic coated over burnt brick aggregate as an alternative material for road construction, Advances in Materials Science and Engineering, Article ID 5352787 (2016)

K. Prem Kumar. "Production of Construction Bricks by Partial Replacement of Waste Plastics." IOSR Journal of Mechanical and Civil Engineering (IOSR-JMCE) 14.4 (2017): 09-12. 